\title{
Legitimacy in Autocracies: Oxymoron or Essential Feature?
}

\author{
Johannes Gerschewski
}

\begin{abstract}
Legitimacy is a key concept in political science. It has deep normative roots in democratic theory and refers usually to righteous, just, fair, and therefore acceptable rule. However, non-democracies also try to create a following among their citizens. They also engage in justifying their rule through politicization, be it of religion, ethnicity, or ideologies ranging from left-wing communism to right-wing nationalism. Against this backdrop, I pose the question: does it make sense to use the concept of legitimacy for both types of regimes, democracies and autocracies alike? Or, do we overstretch the concept when transplanting it to the non-democratic realm? And, empirically, how can we assess to what degree a non-democracy is viewed as legitimate by its citizens? I aim therefore at defining what legitimacy and legitimation is in autocratic settings; drawing a semantic map of rival concepts like support, trust, and loyalty; and tackling concrete challenges in measuring this elusive concept.
\end{abstract}

\section{Legitimacy in an Unlikely Context?}

$s$ there something like legitimacy in autocracies? ${ }^{1}$ Particularly in the 1970s and 1980s, this was a hotly debated question when scholars disagreed about the nature of Soviet-type regimes. While one camp argued that the communist regimes do indeed create legitimacy among its citizens, the other camp criticized these accounts for concept stretching and for neglecting the normative roots of the term legitimacy. ${ }^{2}$ For critics, there was no such thing as legitimacy in autocracies, let alone in communist regimes.

\footnotetext{
Johannes Gerschewski is a Lecturer at Humboldt-Universität $z u$ Berlin where he has also received his PhD in 2014 (johannes.gerschewski@hu-berlin.de). His research interests revolve around comparative authoritarianism, in particular autocratic political thought. He is currently finishing a book manuscript, entitled Organized Certainty? Why Autocracies Remain Stable, that provides a macro-theoretical account of why some autocratic regimes stabilize their rule while other collapse. For excellent comments and enormously helpful suggestions, he would like to thank the anonymous reviewers of Perspectives on Politics as well as their former and current editors, Jeffrey Isaac and Michael Bernhard. He would also like to thank Alex Dukalskis, Farrah Hawana, Bernhard Weßels, Wolfgang Merkel, Christoph Stefes, Alex Schmotz, Dag Tanneberg, as well as the participants of the 2016 ECPR Joint Sessions of Workshops and the 2016 meeting of the DVPW section "Democracy Research" for their generous advice on earlier versions.
}

This debate is not an outdated one among oldfashioned scholars and Kremlinologists. Instead, it is a timely endeavor that has not lost its relevance for political scientists and practitioners. Around the world, we currently observe a rise of autocratic leaders who claim to be legitimated by their people. Ranging from Vladimir Putin in today's Russia, to the general secretaries of China's one-party-rule, but also to political leaders like Recep Tayyip Erdoğan in Turkey and Viktor Orbán in Hungary who gradually slid into authoritarianism, all of them claim to be entitled to rule by their citizens.

The question of whether there is something like legitimacy in autocracies has also resurfaced in academia. Today, we know more about the inner workings of non-democratic regimes. In recent years, social sciences observed a renaissance in the study of comparative authoritarianism. ${ }^{3}$ Key institutions have been analyzed: from political parties ${ }^{4}$ to elections, ${ }^{5}$ from parliaments ${ }^{6}$ to informal power sharing arrangements. ${ }^{7}$ These institutions are understood to be crucial for autocratic rule.

Within this renaissance, a new strand of research has picked up the old legitimacy debate and asked whether autocratic regimes-besides using repressive techniques and co-opting potential elites - do stabilize their rule by seeking the support of the people. ${ }^{8}$ From a rational perspective, this would make sense for the autocratic regime: Repressing opposition is a costly endeavor-at least in the long run. Repression creates counterproductive incentives as it spikes protest. From the autocrat's perspective, these unintended consequences need to be avoided. ${ }^{9}$ These researchers argue therefore that autocratic regimes need to legitimate their rule in order to maintain stable over a longer time period. Unless 
the regimes are mere kleptocracies or sheer tyrannies, they need to furnish a persuasive raison d'etre.

In this light, this conceptual essay analyzes the capacity of the concept "legitimacy" to travel to the nondemocratic realm. It poses the following questions: Is legitimacy the proper concept for social scientists to describe that autocratic rulers seek the support of the people? Or, do we overstretch the concept (and even fall in the trap of autocratic leaders) when we apply it to nondemocratic rule? In other words, is "legitimacy in autocracy" an oxymoron, a "wooden iron," or does it refer to an essential and stabilizing feature of autocratic rule? And finally, if legitimacy is indeed the proper concept, how do we know it when we see it?

The remainder of the essay is structured as follows. I will first argue how we can define such a concept for autocratic regimes. Based on this definitional discussion, I will draw a semantic map of neighboring concepts and discuss their respective strengths and weaknesses. I will then clarify where the differences between legitimacy in autocratic and democratic regimes lie. I will expose the challenges posed by measurement, followed by a brief conclusion.

\section{Systematizing Concept Analysis: The Ogden-Richards Triangle}

A good starting point for any kind of concept analysis is the Ogden-Richards triangle. ${ }^{10}$ It displays a trilateral relationship between the given name of a concept, its meaning (intension), and its empirical referent (extension). Take the following intuitive example: A "table" (name) has the minimal meaning of a raised levelness (intension) that refers, e.g., to a range of empirically observable tables in a seminar room (extension). The relationship between these three corners of the triangle is not always as straightforward as in this example. If we translate the basic linguistic triangle to the social science world, several challenges arise. Yet a systematic diagnosis of a concept takes seriously the relationships between name, intension, and extension (please see figure 1).

Let us first consider the relationship between name and meaning. While, according to the famous French linguist de Saussure, the name is given arbitrarily and usually based on social convention, the relationship between the name and the intension can be plagued by conceptual ambiguity. A 1:1 relationship between a given term and its intension may have been desired since Aristotle's classic works, but the majority of today's linguists agree that language is much fuzzier. In particular, the polysemic nature of concepts (one word, many meanings) troubles the work of social scientists considerably. Concepts cannot be clearly distinguished from each other but instead overlap and so leave room for multiple interpretations. Together with their neighboring concepts, concepts form "semantic fields" that can be mapped. ${ }^{11}$ Moreover, the relationship between the name and the meaning of a concept can suffer from definitional shortcomings. In general, the definition must be as sharp and parsimonious as possible, and the defining features should inhibit sufficient discriminatory power vis-à-vis other features. The set of defining features should also be jointly exhaustive and should be established at the same level of abstraction. A further demand is that a definition should not include contradictory features.

Secondly, when it comes to the delicate balance between the name and the empirical referent, the core question is how do we know it when we see it? How do we identify an empirically observable object as being subsumed under the term? Like identifying that the piece of furniture is a table, we similarly need to identify legitimacy and legitimation efforts as such when observing them in an empirical instance. This, of course, is not a trivial challenge.

Lastly, the balance between intension and extension has found its way into the social sciences under the term "ladder of abstraction." ${ }^{12}$ The relationship between intension and extension is inverse; an increase in the intension leads to a decrease of extension. If one adds to the intension (e.g., color, number of legs, material) to "table," the empirical counterparts of tables to which this new intension matches decreases. In other words, if a table is not only defined by raised levelness, but also by having four legs and being composed of wood, then the number of empirical referents falls. This basic insight requires an apt calibration in choosing not just the right conceptual components, but also an adequate number and range of them in order to avoid over-determination and vagueness. When conceptualizing legitimacy in autocracies, this will be an important caveat.

In the following section, I will discuss the fruitfulness of applying the concept of legitimacy to non-democratic

\section{Figure 1 \\ The Ogden-Richards triangle}

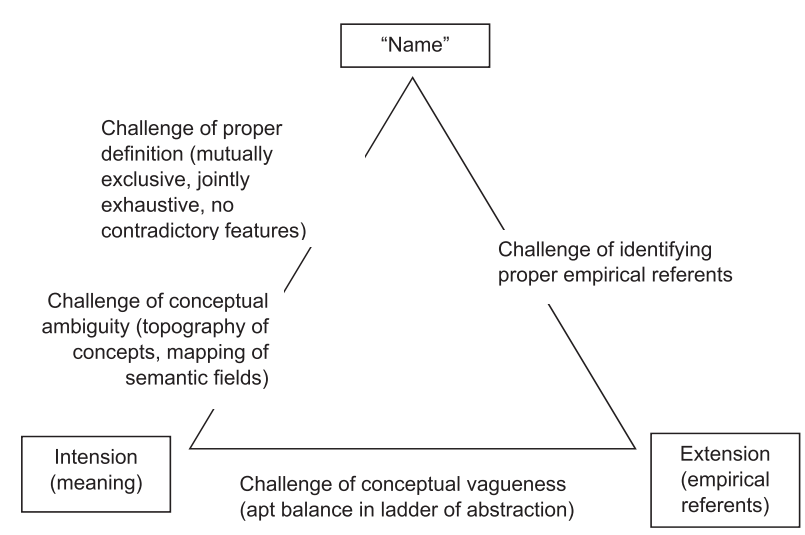


settings by discussing the respective bilateral relationships between name, intension, and extension.

\section{Name versus Intension: Defining Legitimacy in Autocratic Settings}

The biggest challenge in the relationship between name and intension (meaning) lies in avoiding conceptual ambiguity. Ideally, concepts should be delineated from each other. A primary way to do so is to define the concept, i.e., in the literal sense to set its borders. Based on a definition of legitimacy, I will then draw a semantic map of its three most prominent, neighboring, and rival concepts: support, trust, and loyalty.

\section{A Definition}

Etymologically, legitimacy is "according to the law" (legi intimus). ${ }^{33}$ For centuries, the term has been used to distinguish tyrannical rule from right and just rule. Throughout its conceptual history it has been used to describe democratic polities. It carries a strong positive connotation. "Legitimate" is equated with being good and fair; it is understood as being just, and therefore acceptable.

However, the term legitimacy has also non-normative roots. This line of its conceptual legacy goes back to the strictly empirical usage of legitimacy in Max Weber's work. In general, Weber strived to free the term from normative ballast by arguing that we should not focus on how a rule ought to be, but rather to account for how it is. ${ }^{14}$ Weber argued in favor of an empirically observable "belief in legitimacy." 15 That paved the way for a usage of the term beyond normative democratic theory. And indeed, if we take Weber's three types of legitimate rule, the legal-rational, the traditional, and the charismatic rule, two of the three have non-democratic roots. Only the legal-rational type of rule refers to the adherence to (mostly democratic) procedures.

Legitimacy is a relational concept arising between the ruler and the ruled. Rule (or more generally domination) is classically defined as the "probability that certain specific commands (or all commands) will be obeyed by a given group of persons." ${ }^{16}$ As such, Weber sees domination/rule as a subset of power. In a dyadic relationship between a superior $A$ and an inferior $B$, the difference between power and rule lies in the attitude of $\mathrm{B}$ towards $\mathrm{A}$. Power lets $B$ do what $A$ wants, irrespective of her attitude. In a rule relationship, $B$ acknowledges the authority and sees the entitlement claim of $\mathrm{A}$ as being justifiable. $\mathrm{B}$ believes in the right of $\mathrm{A}$ to rule. The transmission belt between $\mathrm{A}$ and $\mathrm{B}$ is therefore one of command and obedience. It has its roots in the study of military organizations. Its major value is discipline and discipline is habitually trained. Weber captures this transmission belt in the German original aptly as "Gehorsamspflicht," i.e., the obligation to obey. ${ }^{17}$

In an influential critique, Beetham has argued that Weber's legitimate rule typology is severely flawed. For him, it collapses several dimensions into one. Beetham disentangled the implicit dimensions and argued that we should make the multi-dimensionality of the concept explicit. For him, three criteria need to be assessed individually: legality, justifiability, and the concrete expression of consent. ${ }^{18}$ These three criteria, although developed in reference to democratic polities, can be made fruitful for the study of non-democratic polities as well.

Beetham argued that power needs to be "acquired and exercised in accordance to the established rules." ${ }^{19}$ By so doing, it is oriented towards the Weberian ideal type of legal-rational rule and the etymological legalistic origin of the term. This poses difficulties in translation to nondemocratic contexts. Legality usually goes hand-in-hand with democratic rule. Yet if we follow a narrower understanding, i.e., of "settled expectations" in order to ensure predictability, ${ }^{20}$ then the route to applying legitimacy to autocracies becomes easier to travel. The argument is that only if norms have settled, their effects unfold. Although Beetham has not explicitly argued this way, I understand his first criterion as a necessary condition for legitimacy. Only when the established rules are settled can legitimacy be achieved. As such, it is a prerequisite for legitimacy. Only if people accept the established rules through Weberian habituation over time does this establish the necessary condition for a legitimacy belief by the people. Irrespective of their political content, expectations need to be stable in order to be effective. In this sense, this first criterion can be translated to the realm of legitimacy in an autocratic context.

Secondly, existing norms need to be justified. They do not acquire full force if they remain in a legal sphere. Instead, rulers need to offer a justification of why the rulers are entitled to rule. Rulers need to credibly anchor their legitimacy claim in the hearts and minds of the people. Anchor points can be diverse. On the one hand, historical narratives can be used to differentiate from former rule (e.g., anti-colonial struggle, civil war). On the other hand, narratives can be built that create a religious, ethnic, or ideological unity. Yet it should be noted that this justifiability should not be restricted only to the ruled. But the ruler needs what Barker has called "endogenous or self-legitimation." ${ }^{21}$ Governments must also demonstrate to themselves that they are entitled to rule. It is characteristic to all kinds of governments "just as worship is one of the characterizing activities of religion." ${ }^{22}$

The third criterion refers to the explicit transmission of legitimacy. This can take the form of swearing an oath, of going to the polls, or of organizing a mass rally. There is a variety of legitimating transmission forms. What is important is that there is any action that "confers legitimacy on the powerful." ${ }^{23}$ We know that, for example, communist regimes have been particularly successful in manufacturing a legitimacy transfer by making use of 
rallies, organizations, and holding (symbolic) elections. However, non-communist regimes also engage regularly in (semi- and non-competitive) elections and other events that serve as a transmission belt for acquiring legitimacy.

With these refinements in mind, we can make use of the concepts of legitimacy and legitimation even beyond the democratic realm. We can define it in the following way: Legitimacy is a relational concept between the ruler and the ruled in which the ruled sees the entitlement claims of the ruler as being justified, and follows them based on a perceived obligation to obey. The legitimating norms must constitute settled expectations in order to be fully effective and must be actively transferred. The extent of legitimacy can so be defined as the strength (how deep?) and width (how many?) of the relational bond between the ruler and the ruled.

A last word on the difference between legitimacy and legitimation is in place here. I concur with Barker and other scholars that legitimacy is an ascribed attribute and a property of an object (e.g., a regime), while legitimation refers to the process of gaining legitimacy. While the former is a property, the latter is an action. While the former can be normatively grounded, the latter refers to an empirically observable activity. ${ }^{24}$ It might therefore be in general less "demanding" to talk of legitimation in autocracies (understood as the attempt of the ruler to gain a following) than of legitimacy in autocracies. While most scholars would agree that even autocrats spend time and effort in justifying their rulewhether via propagandistic media channels, political education programs, performance, or even the hosting of prestigious international sport events and spectaclesdemocratic theorists might be tempted to refute the very idea of legitimacy being applicable to non-democratic settings. Due to the term's rich historical lineage and the deep interweavement between legitimacy and a just and fair democratic polity in the history of Western political thought, this refutation takes place on solid ground. ${ }^{25}$ Non-democratic settings entail coercive environments that make invocation of legitimacy inappropriate. For this sceptic view, legitimate authoritarianism remains necessarily a "wooden iron"; it is an oxymoron.

\section{Neighboring Terms of Support, Trust, and Loyalty}

In order to identify the core differences and similarities of neighboring concepts, it is a fruitful endeavor to draw a semantic map. Neighboring concepts that capture the phenomenon that all political regimes try to create a following among its ruled population are support, trust, and loyalty. These rival concepts will be delineated from the concept of legitimacy.

Support is the most neutral and most encompassing term that can be used. Scholars have been more comfortable using this concept in non-democratic contexts. ${ }^{26}$ It does not contain the normative ballast of legitimacy. The concept of support is therefore more rooted in the empirical, sociological tradition than in normative democratic theory. As it stems from systems theory, it also allows an application to all types of political systems. David Easton's long shadow on today's political science is still tangible. Fifty years ago, he defined political support as follows: "We can say that A supports B either when A acts on behalf of $\mathrm{B}$ or when he orients himself favorably toward B. ${ }^{\prime 27}$ In this sense, Easton placed emphasis on both the action and the attitude. Easton distinguished between two modi of support. Diffuse support is long-term oriented and represents "a reservoir of favorable attitudes or good will that helps members to accept or tolerate outputs to which they are opposed."28 Specific support, in turn, is more short-term oriented. Scharpf s output legitimacy that is rather "interest based than identity based" 29 comes close to Easton's specific support. With this in mind, I would suggest the following for delineating support from legitimacy. ${ }^{30}$ While one can support a regime for different reasons, be it either out of ideational conviction or only out of utilitarian cost-benefit calculations, legitimacy necessarily refers to favorable attitudes towards the ruler. In this sense, Easton's diffuse and specific support is more encompassing than legitimacy.

If we cross-tabulate attitude and behavior and use the rather coarse-grained values of "pro-regime," "antiregime," and "indifferent," then the matrix in Table 1 can be constructed. ${ }^{31}$ It demonstrates both the overlap and the difference between the two concepts. I have added in the fourth column a possible description for how we could name these actors.

I suggest that in order to apply the concept of legitimacy, the belief of the people must be necessarily either pro-regime or at least politically indifferent. I read Easton's definition of support ("A supports B either when $A$ acts on behalf of $B$ or when he orients himself favorably toward B") 32 as being connected with a logical "OR." Therefore, either the belief or the action must be present.

With this in mind, I propose that the overlap between the two concepts occurs from type 1 agents (true believers) through type 3 agents (unmobilized supporters). They all hold a pro-regime belief regardless of their behavior. Holding political indifferent beliefs while displaying proregime behavior, type 4 agents might be perceived as controversial. They are either conformists, careerists, or just apathetic followers. For the distinction between support and legitimacy, this is a borderline case. A strict application of legitimacy as being in favor of the regime would exclude these people. Being indifferent is not necessarily believing; therefore, this group would not fall in the legitimacy camp. A looser understanding of political indifference, however, would include this group. While it is clear that these type 4 agents support the regime with their behavior (and so stabilize it), they are the undetermined, wavering group of people. On the mass level, they 
Table 1

Belief versus behavior

\begin{tabular}{llllll}
\hline Type & Belief & Behavior & \multicolumn{1}{c}{ Name for Actors } & Legitimacy & Support \\
\hline 1 & Pro-regime & Pro-regime & True believers, convinced supporters & yes & \\
2 & Pro-regime & Anti-regime & Strategic coup plotters & yes \\
3 & Pro-regime & Indifferent & Unmobilized supporters of regime & & \\
4 & Indifferent & Pro-regime & Conformist and apathetic followers, careerists & no & yes \\
5 & Anti-regime & Pro-regime & Opportunists (As-if-action) & no & no \\
6 & Anti-regime & Indifferent & Unmobilized and repressed opposition & & \\
7 & Indifferent & Anti-regime & Mobilized by opposition & \\
8 & Anti-regime & Anti-regime & Activist, true opposition &
\end{tabular}

are apathetic and conformist. On the elite level, they would pursue a (political) career-irrespective of the regime form. As these groups ultimately decide to act in favor of the regime, I tend to classify them inside and not outside the legitimacy rubric.

Type 2 agents also need some more elaboration. They have in general a pro-regime attitude, but undermine the regime stability with anti-regime behavior. Usually, this group tends to be rather small. They follow a strategical plan to come to power themselves by plotting a coup against what Svolik described as the "ruling coalition." 33 However, they share the same favorable general attitudes towards the regime and view it as the appropriate form of government. Type 5 actors (opportunists) mark an important difference. They are characterized by an antiregime attitude and a pro-regime behavior. Against this backdrop, this group can be delineated from type 4 agents. They are opportunists and not conformist. They act as if they were in favor of the regime, but they are not. Lisa Wedeen's important ethnographic study on Syria of Hafiz al-Asad is one of the accounts in which this "as if action" is portrayed. Surrounded by an immense personality cult, Syrians acted as if they revered the leader-which, in turn, installed a subtle and habitualized obedience into their hearts and minds. ${ }^{34}$ This group of people, whose size varies over different regimes, supports the regime without viewing it as legitimate.

The distinction between support and legitimacy can be traced back to the different motivations why a person supports a regime. People who holds anti-regime beliefs but act as if they were in favor of it follow a utilitarian motivation based on cost-benefit calculus. They do not support the regime because they view it as being entitled to rule, but rather out of strategic considerations and out of the sheer fear of repression. Of course, social science scholars should abstain from a holier-than-thou attitude and eschew moral judgements of this group. These actors keep quiet as they know that acting according to their beliefs will pose an often existential threat to them. What can be stated is that type 4 agents (conformists) constitute a borderline case in which the regime might be viewed as legitimate, while type 5 agents clearly do not do so.

Type 6 through type 8 agents describe different facets of the opposition. Type 8 is the mirror image of type 1 agents. It is the group of people that form the true and active opposition that view the regime as being illegitimate and act accordingly. Type 6 and type 7 agents are then groups that are either repressed and therefore remain passive or represent the wavering group that can be mobilized by the opposition. What is important to note is that when cross-tabulating attitude and behavior, we can identify a considerable overlap between legitimacy and support. However, the difference lies in the group of "as if actors" that mark the difference in the conceptual scope.

A second neighboring and rival concept is political trust. Easton's diffuse and specific support had a lasting influence on this concept as well. ${ }^{35}$ In survey research, a battery of questions is usually asked. Survey items like trust in the government, the party, the parliament, the military, or the police, etc. are widespread. In this light, Levi and Stoker have summarized "a minimal consensus." For them, trust is — like legitimacy-relational. It involves an "individual making herself vulnerable to another individual, group, or institution that has the capacity to do her harm and to betray her." ${ }^{36}$ In a similar vein, Kaase has defined trust as both asymmetrical and relational. ${ }^{37}$ There is one dominant $\mathrm{A}$ (government) who is trusted by a subordinate B (citizen). B trusts that A acts in B's interest. However, B cannot be sure about A's real intentions. Therefore, trust can be understood as "encapsulated interest." 38 Trustworthy is then someone who credibly acts in the interest of the truster-and who has the actual competence to do so. ${ }^{39}$ Trust is therefore instrumental and evaluates the performance and effectiveness of the trustee.

With this in mind, the semantic overlap between legitimacy and trust lies in its relational character between a dominant $\mathrm{A}$ and a subordinate $\mathrm{B}$. Both relationships are 
asymmetric, between the trustee and the trusted and between the ruler and the ruled. However, there is nuance in the trust concept that refers to the competence of the trustee to fulfill the interest of the truster. Trust as encapsulated interest speaks more to a performative side of legitimacy while tending to neglect the ideational side. It can therefore be seen as a subset of legitimacy. Trust is also a subset of legitimacy in a second instance. Trust tends to refer to more concrete institutions like government, party, or parliament. It is rarely invoked in reference to the broader community and the identity of a nation. This is the realm of legitimacy. At least in the Weberian understanding of legitimate rule, legitimacy seems to be the more adequate term to characterize political rule and regimes as a whole.

Lastly, loyalty is also defined here as a partial subset of legitimacy. I argue that loyalty differs from legitimacy in important ways. A narrow definition of loyalty refers to an emotional, deeply affective, and non-rational attachment to a group. ${ }^{40}$ Loyalty "adds a layer of faithfulness and utmost reliability." ${ }^{41}$ In most accounts, loyalty is an inter-human relationship that is asymmetrical, often hinting "subservience and inequality" 42 of the subordinate $B$ vis-à-vis the dominant $A$. In contrast, legitimacy, support, and trust are less imbued with this non-rational faithfulness.

Loyalty is also rather reactive. Consider the canonical book by Hirschman, Exit, Voice, and Loyalty. ${ }^{43} \mathrm{He}$ understood these options as "responses to a decline in firms, organizations, and states." In a deteriorating situation, the two basic responses are either to leave or to voice discontent. The function of loyalty is then twofold: it "holds exit at bay and activates voice." ${ }^{44}$ As such, loyalty acts as a crisis catalyst. ${ }^{45}$ Loyalty can be observed most clearly in a direct reaction to a crisis situation. When being challenged, loyalty becomes more obvious.

Yet, there is a general danger of confusing the observability of a phenomenon with its definition. To some extent, trust works the same way as loyalty. When being challenged, trust becomes easier to observe. A given challenge can be the litmus test by which scholars can decide if $B$ trusts $A$ or not. Yet being challenged is not part of the definition of trust. Citizen B can trust her government $\mathrm{A}$, regardless of whether it ever faced difficulties. Loyalty with its connotation of faithfulness, commitment, and emotional bonding strongly incorporates the idea that it is a crisis reaction. I follow here Gert, who argued that loyalty "requires an individual to be willing to make significant personal sacrifice." 46 Despite problems, troubles, and challenges, subordinate $B$ remains loyal to dominant A and accepts personal costs. Loyalty inherently implies a concessive conjunction. I argue that loyalty follows the slogan "right or wrong, my country/my king/ my boss/my family" etc. Ups and downs are almost necessary to speak about loyalty. At least a case could be made that loyalty is not only seen most clearly in times of crisis, but that a challenge of any sort is a prerequisite for even using the concept. As such, loyalty is a robust and stretchable bond, but might tend to be less durable and persistent.

One does not need to follow this line of argument to the end, but what is important to note is the following: Even if I view an action, a decision, or a regime as bad, wrong, false, or illegitimate, I can remain loyal. Legitimacy, instead, would require that I view the action as being justified. This is why loyalty is a partial subset of legitimacy. The sets can overlap when actors are loyal to a regime that they view as legitimate. But they can also remain loyal even if they view the regime as illegitimate. Loyalty can also be delineated from legitimacy with regard to the addressee. While legitimacy refers to the population in general, loyalty tends to refers to a smaller circle of people. Loyalty is usually elite-centered. This has to do with potential future gains that motivate loyal behavior. The cooptation literature in comparative authoritarianism highlights this point. Notably, this strand of literature understands loyalty in a political economy perspective. For them, loyalty is not based on deep affection, but rather on rational cost-benefit calculus. The argument is straightforward: cronies remain loyal and do not revolt against the regime as long as they can be bought off via policy concessions, material spoils, or other revenues - or at least as long as the assurance that they benefit from the current regime is credible. ${ }^{47}$ Facing hard budget constraints, loyalty needs to be focused on key persons and can only be in rare circumstances dispersed to the masses.

If we stick to the original definition of loyalty and maintain that a group remains loyal out of deep conviction, then the size of this group is usually also restricted. This group is then populated only with the type 1 actors described above. These are the true believers and it is empirically very rare that a society is composed only of true believers. Even North Koreans, as currently the most homogenous and by far the most indoctrinated society today, is viewed in newer research as much more fragmented than common images of the country might depict. ${ }^{48}$ Loyalty tends to be more of an elite, rather than a mass, phenomenon.

Loyalty is therefore a partial subset of legitimacy. It has a stronger connotation of an affective, even non-rational faithfulness. It works as a catalyst that postpones exit and strengthens voice. It is reactive in a sense that despite problems, despite viewing an action or a regime as wrong or illegitimate, actors can remain loyal. Lastly, loyalty is usually restricted to a smaller group of people and is elite centered.

To sum up, major neighboring concepts to legitimacy are support, trust, and loyalty. Support is a superset of legitimacy as it also subsumes actors under its semantic 
umbrella who hold anti-regime beliefs but act as if they were actually in favor of the regime. Trust and loyalty are (partial) subsets of legitimacy. While the former refers to encapsulated interests and therefore more to a performance evaluation, the latter is a more elite-centered, emotional attachment that remains despite problems and challenges. As such, legitimacy can be placed in the middle between support on the one hand and trust and loyalty on the other hand. The concepts are therefore different in scope. They can embrace actors who both support the ruler, view her as legitimate, trust her, and remain loyal even in contested times. However, the Venn diagram in figure 2 shows also that this is not necessarily the case. Actors can be loyal and supportive despite viewing the regime as illegitimate.

\section{Extension versus Intension: Finding a Balance in the Ladder of Abstraction}

The relationship between extension and intension, i.e., between empirical referents in the outside world and semantic meanings of a term, has been popularized in the social science by Giovanni Sartori. Using the "ladder of abstraction" (sometimes also "ladder of generality"), ${ }^{49}$ scholars attempt to find a balance between defining features on the one hand and empirical referents on the other. The relationship is inverse. Increasing intension leads to a decreasing of extension and vice versa. This basic insight demands therefore from social scientists an apt calibration in not only choosing the right features, but also thinking carefully about an apt number and range of conceptual components. In this sense, I use the ladder of abstraction as a definitional tool that helps in distinguishing minimalist from maximalist understandings of legitimacy.

\section{Figure 2}

\section{Semantic map}

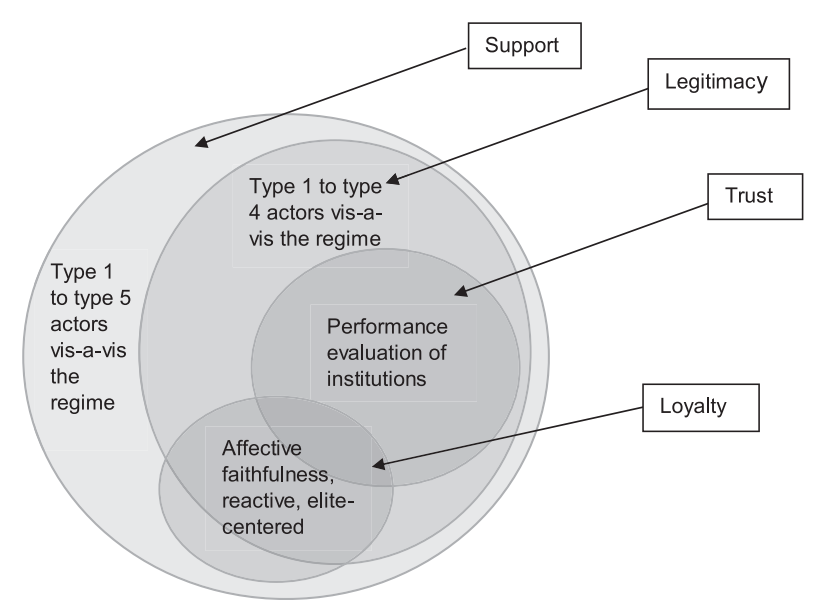

Legitimacy incorporates various defining featuresdepending on "which satisfy the criteria laid open by the observer." ${ }^{50}$ Weatherford has summarized them in four points that appear across a large body of literature: (1) accountability, (2) efficiency, (3) procedural fairness, and (4) distributive fairness. ${ }^{51}$ Levi and colleagues would argue that the most important elements for a "valuebased legitimacy" are (1) the trustworthiness of the government (that in turn depends on the performance, the leadership motivations and the administrative competence) and (2) procedural justice. ${ }^{52}$ Gilley has also grouped a long list of suitable indicators into five "schools": (1) the particularistic, (2) the sociological, (3) the developmental, (4) the democratic, and (5) the bureaucratic. ${ }^{53}$ While the particularistic school highlights the time and context sensitivity of the concept that makes generalizations difficult, the other four are more substantial. The sociological school underlines social and cultural conditions that create a feeling of belonging; the developmental school is preoccupied with the evaluation of allocation and distribution of goods; the democratic school is concerned with just and fair procedures; and, finally, the bureaucratic school refers to the strength and effectiveness of state institutions. The expansiveness of these lists might suffice to drive home the point. There exists a magnitude of defining features for when we can speak of legitimacy of political regimes. On an even more basic level, one might be tempted to include free choice and voluntary consent into such a definition in the first place.

The ladder of abstraction assumes in general that the defining elements stand in a necessary and sufficient condition structure. ${ }^{54}$ I follow this assumption here and argue that that the defining elements of the list stand in a hierarchy. Going up the ladder one step therefore means adding a defining feature. If we use a maximalist conception of legitimacy and include all definitional features, the empirical referent side containing concrete autocratic regimes will be (almost) empty. If we apply minimalist conception, then the empirical referent box will therefore be more populated (please see figure 3). ${ }^{55}$ Consequently, to apply the concept of legitimacy and legitimation in nondemocratic contexts means to curtail its semantic range at a lower level. Only sociological, developmental, and bureaucratic conceptions of legitimacy can be used to identify empirical non-democratic referents. However, procedural features are increasingly gaining importance with the global spread of "electoral" and "competitive authoritarianism." 57

Without doubt, using the concept of legitimacy in non-democratic contexts contains an inherent danger. Such analysis can be misused to apologize and relativize autocratic rule, and might go so far to defend the normative foundations of a concrete autocratic regime ruling in a specific country. However, this is not the 


\section{Figure 3 Ladder of abstraction for the concept of legit- imacy}

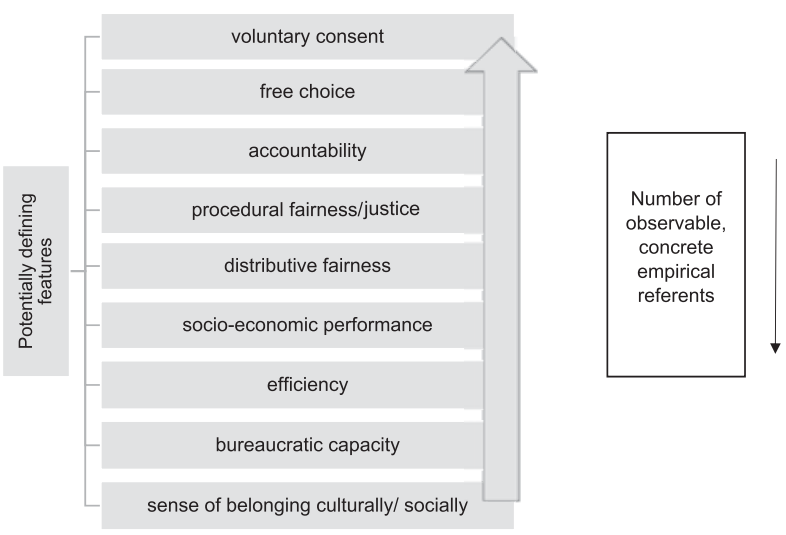

intention behind making the concept applicable to autocracies. Instead, it has been shown above that neighboring concepts can also be used, but that these carry a different semantic nuance and empirical scope. Legitimacy-used here in the empirical-analytical tradition-only refers to the phenomenon that nolens volens some people in autocratic regimes do believe that their rulers are entitled to rule to some extent.

What we can learn from the list of definitional features, however, is that there are domains that remain reserved for democratic polities. While autocracies can refer to a basic sense of belonging in underlining nationalist argumentation patterns or can even exceed democracies with regard to bureaucratic capacities, efficiency, and economic growth, they are mostly blank when it comes to "deeper" values of political rule like fairness, consent, and the respect for human rights. Here, autocracies are often mute or evasive. When autocracies need to justify their right to rule, i.e., a kind of second-order justification, they need to curtail the discourse at a certain level in order to succeed. A hypothesis for future research could be generated here: the more an autocratic regimes climbs up the list of defining features in justifying its right to rule, the less it says about fundamental values. While its speeches, news, and texts are full of reference to nationalism or religion as a source of belonging and praise for economic efficiency and wellbeing, clear indications for procedural and consensual values remain sparse-if mentioned at all.

\section{Name versus Extension: How Do We Know It When We See It?}

In general, the naming of a phenomenon-with some rare exceptions like onomatopoeia-is arbitrary and does not follow a certain motivation. For the purpose of this essay, I extend the mere linguistic relationship between name and extension to the methodical challenge of identifying proper empirical referents. We attach the name "table" to any object with a raised levelness that we observe in a class room. This is an easy endeavor. However, how should we name what we observe, let's say in today's rural Russia? Do people there view Putin's rule as "legitimate"? And what are the instruments out of our social science methods toolbox to identify this belief as legitimacy? When can we use the name "legitimacy" for an empirical phenomenon that we observe? Or, more bluntly: how do we know it when we see it?

Of course, the methodological challenge of applying the concept of legitimacy to empirical reality does not apply to autocratic regimes solely. The most powerful criticism of the concept is that it is difficult to empirically observe. This line of critique argues that legitimacy is a property that is only observable when it is gone, or at least when it is in decline. Only if legitimacy is gone or in sharp decline, does it have some influence on observable variables, such as stability. It is a dilemma that-in the eyes of the critics-is unsolvable. ${ }^{58}$ Przeworski has led the group of critics to a second and related argument. For him, the entire concept of legitimacy should be dismissed when explaining macro-phenomena like stability, on the ground that "isolated individuals do not shake political orders." Przeworski argues that if legitimacy is understood in an individualist sense (as done in this essay), it has only "little bearing on the issue of stability," interests matter. So, while one faction of critics insist that we can only see legitimacy in decline as it then triggers observable phenomena like stability, a second declares that it lacks even this influence. These are the severe challenges on the democratic side; the challenges on the autocratic side of the regime spectrum are even more difficult. ${ }^{60}$

There are two routes by which we can attempt to measure legitimacy: survey research and behavioral indicators. Survey research constitutes in general the gold standard in knowing what people actually believe. However, this is very challenging in autocratic settings. Social scientists face a doubly troubling situation. On the one hand, some questions are too politically sensitive to be asked. (Self-)Censorship prevents us from knowing what people actually believe. On the other hand, the respondents face an incentive structure in which they rather answer what is socially desirable and less risky for their own physical integrity. As a result, preference falsification is widespread. ${ }^{61}$

Nevertheless, I would like to encourage survey researchers to think more thoroughly of legitimacy questions. Recently, the sixth wave of the European Social Survey has pioneered this type of research. They have explicitly included a battery of detailed questions that measures the legitimacy dimension. ${ }^{62}$ It has been designed with a view on democracies. However, what we 
could learn for the autocratic pole is their construction. They argue that we need a distinction between what people think how democracy should look and how it actually is. Following this line of research, I would propose a third dimension besides expectation (how it should be) and evaluation (how it is). For autocracies, we should also aim to include questions on the official legitimacy claim of the regime.

This would leave us in future research with a double yardstick. On the one hand, an open question should inquire what characterizes a good political order in the eyes of the respondents. This question could be a functional equivalent for the questions what democracy means to you. It refers to the expectations of the citizens. On the other hand, survey questions should inquire about the official legitimacy claims of the regime. These questions need to uncover how often a government refers to certain justification, how much emphasis the government places on it, and if we can observe subtle shifts over time. ${ }^{63}$ The obvious challenge for social scientists lies in compiling a list of possible legitimacy claims in autocratic settings. ${ }^{64}$ The list should be exhaustive, but does not need to be mutually exclusive as legitimacy formulae are often a mélange of different elements.

These two yardsticks would inform us how the rule should be from the perspective of the ruled and how the rulers officially justify their rule. In a second step, these dimensions should be confronted with the evaluation of the respondents: to what extent are your expectations fulfilled? And to what extent do the beliefs of the people (e.g., in your family/ your neighborhood/ your workplace) meet the claims of the regime? It goes without saying that these questions are politically sensitive and a neutral way of formulating must be found. They will suffer from preference falsification. ${ }^{65}$ Yet what I tentatively propose here is push the debate forward. The most promising route seems to me to follow a triangular structure (expectation, claim, belief) and argue that only if these dimensions converge, we can assume that an autocratic regime is viewed as legitimate.

Survey research is difficult and sometimes just impossible in autocratic settings. In-depth, qualitative fieldwork is then the only route that uncovers the complexity of autocratic legitimacy. Expert surveys by which country experts judge to what extent they think what the people think can be a complementary source of information. ${ }^{66}$ Such surveys pool the expertise of case-specific knowledge and try to combine the best of two worlds: the qualitative case knowledge by assuring the comparability across cases. Yet it should be clear that expert surveys on legitimacy in autocracies can only express the (expert's) evaluation of the (people's) evaluation. When it comes to the official legitimacy claims of the regime, these can be distilled by using qualitative and quantitative text analyses of representative texts. Speeches, official newspapers, or even textbooks in school curricula are innovative ways of approaching the question how these regimes justify that they are entitled to rule. ${ }^{67}$ The alternative to survey research is a measurement via observable phenomena. Research on democracies has established tax compliance as an apt behavioral indicator for measuring legitimacy. The higher the share of people is that comply with tax rules, the more a regime is viewed as legitimate by the people. ${ }^{68} \mathrm{In}$ earlier work, Levi has also studied voluntary military service as an adequate indicator. ${ }^{69}$ The selection of a suitable indicator for the autocratic pole must be driven by similar concerns: Do we find an empirically observable behavior that is not caused by repression, but instead demonstrates by and large a voluntary act that is motivated by perceiving the current rule arrangement as being justified.

The most intuitive datum in this regard is mobilized political protest. The argument is straightforward: if people protest, they show their dissatisfaction with the ruler. However, protest cannot be equated with nonlegitimacy. Not all protest is protest against the incumbents. We need to inquire more in depth who protests and why these people protest? This brings again survey research into play. The recent Arab uprisings have shown that social scientists attempted to collect this information about protesters' motivations. ${ }^{70}$ When going beyond the size and frequency of protest, and inquiring into the motivations, a necessary step is to use protest as a valid indicator for legitimacy. However, there are two further methodical caveats. Firstly, we tend to focus one-sidedly on successful cases of protest and overlook negative cases. Non-protest also cannot be equated with legitimacy. Secondly, we tend to overestimate the effect of declining legitimacy if we do not control for the effect of repression. Roughly speaking, protest emerges out of a conjunction of declining legitimacy and declining repression. When a window of opportunity opens by less repression, protest becomes just more probable. If we take protest as a mere indicator for declining legitimacy, we fail to account for this basic relationship between repression and protest possibility.

A promising alternative behavioral indicator has recently been brought forward by Dimitrov. ${ }^{71} \mathrm{He}$ finds that in communist regimes people submitted official citizen complaints. These complaints were targeted at material issues (housing, car, etc.), but also raised political issues. Not unlike compliance with taxation, the magnitude and content of citizen complaints can tell us something about the extent to which the ruled see the rulers as legitimate. In a similar vein, the responsiveness debate has sparked scholarly interest for the cases of Vietnam and China. Based on novel data, it has been shown that responsiveness and legitimacy plays an important role in the resilience of these autocratic regimes. ${ }^{72}$ The same holds true for related conceptions of "consultative authoritarianism" 73 and 
Table 2

Methodological approaches to the study of legitimacy in autocracies

\begin{tabular}{|c|c|c|c|c|}
\hline & $\begin{array}{l}\text { Expectation } \\
\text { (yardstick I) }\end{array}$ & $\begin{array}{l}\text { Official Claim } \\
\text { (yardstick II) }\end{array}$ & $\begin{array}{c}\text { Legitimacy } \\
\text { Belief }\end{array}$ & Action \\
\hline $\begin{array}{l}\text { Methodical } \\
\text { approximation }\end{array}$ & $\begin{array}{l}\text { - Qualitative fieldwork } \\
\text { - Survey research }\end{array}$ & $\begin{array}{l}\text { - Quantitative and } \\
\text { qualitative text } \\
\text { analysis } \\
\text { - Survey research }\end{array}$ & $\begin{array}{l}\text { - Qualitative fieldwork } \\
\text { - Survey research }\end{array}$ & $\begin{array}{l}\text { Observable datum, } \\
\text { behavioral indicator } \\
\text { (protest, citizen } \\
\text { complaints, etc.) }\end{array}$ \\
\hline $\begin{array}{l}\text { Methodological } \\
\text { challenge }\end{array}$ & $\begin{array}{l}\text { - Comparability } \\
\text { - (Self-) Censorship } \\
\text { - Preference } \\
\quad \text { Falsification }\end{array}$ & $\begin{array}{l}\text { - Representative text } \\
\text { corpus } \\
\text { - (Self-) Censorship } \\
\text { - Preference } \\
\text { Falsification }\end{array}$ & $\begin{array}{l}\text { - Comparablity } \\
\text { - (Self-) Censorship } \\
\text { - Preference Falsification } \\
\text { - For expert surveys: } \\
\text { "Evaluation of an } \\
\text { evaluation" }\end{array}$ & $\begin{array}{l}\text { Isolation of effect of } \\
\text { legitimacy }\end{array}$ \\
\hline
\end{tabular}

Source: Author

"authoritarian deliberation." 74 Here it is argued that autocracies consult their citizens and provide participation channels in order to increase the legitimacy of offices, regulations, and laws. ${ }^{75}$ It should also be noted that these debates about responsiveness, consultation, and deliberation in unlikely settings demonstrate that legitimacy does not need to remain on a macro-regime level. While Weber's three types of legitimate rule have traditionally focused on the regime as a whole and a general narrative, newer research provides a micro-foundational perspective. These newer studies not only look at more concrete (and tangible) laws and regulations, but also break down their empirically driven, fine-grained analysis to local and regional levels. As such, we can observe a growing conceptual flexibility beyond the nation-state. Moreover, natural experiments have been used to inquire into the influence of foreign media exposure on public support in autocracies. $^{76}$ Semi-structured interviews and online observatory participation has increased our understanding in how autocracies foster an ideological belief among its citizens. ${ }^{77}$ What these works unite is their innovative approach to studying how and to what extent autocracies try to legitimate their rule (please see table 2). This methodological creativity is needed in future research.

\section{Conclusion: Why Should We Care about Studying Legitimacy in Autocracies?}

The question of legitimacy is a known unknown for autocracies. Autocratic leaders realize that it is important for them to know what people think, but they often lack the information to assess to what extent they are seen as legitimate. Folkloric tales of Oriental and Chinese emperors mingling with the people to learn what they think indicate that it has been a known unknown throughout history. Nazi Germany invested large sums and actually revolutionized survey research in order to ascertain what the people really think. ${ }^{78}$ So even the most brutish regime wants to know what its citizens believe. Today, we have case-based evidence on a range of countries with China and Russia at the forefront and among the most active in fostering a legitimacy belief. ${ }^{79}$

The recent wave of scholarship on authoritarian politics becomes increasingly aware that these regimes try to legitimate their rule. As such, it has become a known unknown in academia as well. The whole innovative potential of social science methods needs to be harnessed in order to gradually learn more about this terrain. However, as Sartori has warned us some decades ago: "the progress of quantification should lag — in whatever discipline-behind its qualitative and conceptual progress." ${ }^{80}$ This conceptual essay has been written in this Sartorian spirit and attempts to increase our understanding of legitimacy in an unlikely political setting. It has made use of the linguistic Ogden-Richards triangle to systematically discuss the concept. While it has offered a definition and a semantical map of rival concepts, it has argued that autocracies can indeed legitimate their rule, but do so on a more superficial level. They need to legitimate their rule with more neutral terms like efficiency, capacity, and performance, but remain by and large silent when justifying their right to rule in a deeper sense. Values of fairness, human rights, and voluntary consent are usually not in the arsenal of autocratic legitimacy claims. Instead, it can be hypothesized that autocracies need to sever the public discourse at this level. This is open to debate. What is not, however, is that the topic has become a major concern in the comparative study of authoritarianism.

\section{Notes}

1 There is a terminological debate about the differences between authoritarian and autocratic regimes. I perceive autocracy as the umbrella term that unites 
different forms of authoritarian, sultanistic, but also totalitarian regimes. As such, it is closest to mark the antipode to democracy.

2 E.g., Rigby and Feher 1982; Pakulski 1986.

3 Geddes 1999, Pepinsky 2014.

4 Brownlee 2007, Magaloni 2006, Smith 2005.

5 Schedler 2013, Gandhi and Lust-Okar 2009.

6 Gandhi 2008, Gandhi and Przeworski 2007.

7 Svolik 2009, 2012; Arriola 2009; Magaloni 2008.

8 Dukalskis and Gerschewski 2017; Kailitz and Stockemer 2015; Grauvogel and von Soest 2014; Gerschewski 2013; Holbig, 2013; Gilley 2009.

9 Davenport 2007.

10 Sartori 1984, 22-23; Gerring 1999; Schedler 2011.

11 Sartori 1970, Freeden 1994.

12 Sartori 1970, 1040-1046; Goertz 2009.

13 Würtenberger 1982.

14 Collins 1986, 155-158.

15 Weber 1978, 213.

16 Ibid., 212.

17 Weber 2005, 129.

18 Beetham 1991.

19 Ibid., 16.

20 Ibid., 65.

21 Barker 2001, 30-40.

22 Ibid., 30.

23 Beetham 1991, 91, italics original.

24 Barker 2001, 22-25.

25 Würtenberger 1982.

26 Geddes and Zaller, 1989.

27 Easton 1965, 159.

28 Ibid., 273.

29 Scharpf 1999, 12.

30 For Easton, legitimacy refers only to the diffuse support towards the political regime and the authorities. The same holds true for trust that is gained via experience (whereas legitimacy is gained via socialization) and that refers also only to the modus of diffuse support for the regime or the authorities. For a discussion, please see the helpful overview by Fuchs and Klingemann 2009.

31 I leave out the group of actors with indifferent belief and indifferent behavior.

32 Easton 1965, 159.

33 Svolik 2012.

34 Wedeen 1999.

35 Klingemann and Fuchs 1995, Norris 1999.

36 Levi and Stoker 2000, 476.

37 Kaase 1999, 2-3.

38 Hardin 1999, 24.

39 Levi and Stoker 2000, 476.

40 Shklar 1993, 184.

41 Freeden 2009, 195.

42 Ibid., 198.

43 Hirschman 1970.

44 Ibid., p. 78.
45 Hirschman 1993.

46 Gert 2013, 4.

47 Gandhi 2008, Magaloni 2008, Svolik 2009.

48 E.g., Haggard and Noland 2011.

49 Sartori 1970, 1040-1046; Goertz 2009.

50 Barker 2001, 9.

51 Weatherford 1992, 150.

52 Levi, Sacks, and Tyler 2009.

53 Gilley 2009, 31-57.

54 Goertz 2006, 27-68.

55 If we were to favor a family resemblance structure, the relationship could be the reverse. An increase in the defining feature would then not lead to a decrease of the empirical referents, but could rather lead to an increase in extension; Goertz 2006, 40-44 and 69-94. A second basic concern of the ladder of abstraction could refer to the hierarchical order of the list that I propose here. The order should be seen as a suggestion and can be re-arranged. Yet the important idea here is that we should distinguish between "thick" and "thin," i.e., between maximalist and minimalist definitions.

56 Schedler 2006.

57 Levitsky and Way 2010.

58 Marquez 2015, O’Kane 1993.

59 Przeworski 1991, 28.

60 von Haldenwang 2017.

61 Kuran 1991, 1997.

62 Weßels 2016.

63 See, e.g., for the Polish case Bernhard 1993, 24-45.

64 Such a list could comprise for the ideational dimension in nationalism, tradition, charisma, religion, ethnicity, historical narrative (e.g., civil war, anti-colonial struggle, independence movement), political ideology, international frontlines. For the performance dimensions the list could include law and order, economic performance, social welfare.

65 Kuran 1991, 1997.

66 Grauvogel and von Soest 2014.

67 Dinas and Northmore-Ball 2017.

68 Levi, Sacks, and Tyler 2009.

69 Levi 1997.

70 Beissinger, Jamal, and Mazur 2015; Thyen and Gerschewski 2017.

71 Dimitrov 2014.

72 Chen, Pan, and Xu 2016; Malesky and Schuler, 2010.

73 Truex 2017.

74 He and Warren 2011; Fishkin et al. 2010.

75 Stromseth, Malesky, and Gueorguiev 2017.

76 Kern and Hainmueller 2009.

77 Dukalskis 2017; Han 2015.

78 Friedrich 1957, 154-160.

79 Gill 2015, Holbig 2013, Holbig and Gilley 2010.

80 Sartori 1970, 1038. 


\section{References}

Arriola, Leonardo R. 2009. "Patronage and Political Stability in Africa." Comparative Political Studies 42(10): 1339-62.

Barker, Rodney. 2001. Legitimating Identities: The Self-Presentations of Rulers and Subjects. Cambridge: Cambridge University Press.

Beetham, David. 1991. The Legitimation of Power. Houndmills: Palgrave Macmillan.

Beissinger, Mark, Amaney Jamal, and Kevin Mazur. 2015. "Explaining Divergent Revolutionary Coalitions: Regime Strategies and the Structuring of Participation in the Tunisian and Egyptian Revolution." Comparative Politics 48(1): 1-24.

Bernhard, Michael. 1993. The Origins of Democratization in Poland: Workers, Intellectuals, and Oppositional Politics, 1976-1980. New York: Columbia University Press.

Brownlee, Jason. 2007. Authoritarianism in an Age of Democratization. Cambridge: Cambridge University Press.

Chen, Jidong, Jennifer Pan, and Yiqing Xu. 2016. "Sources of Authoritarian Responsiveness: A Field Experiment in China." American Journal of Political Science 60(2): 383-400.

Collins, Randall. 1986. Weberian Sociological Theory. Cambridge: Cambridge University Press.

Davenport, Christian. 2007. "State Repression and Political Order." Annual Review of Political Science 10: $1-23$.

Dimitrov, Martin K. 2014. "What the Party Wanted to Know: Citizen Complaints as a "Barometer of Public Opinion' in Communist Bulgaria." East European Politics and Societies and Cultures 28(2): 271-95.

Dinas, Elias and Ksenia Northmore-Ball. 2017. "The Ideological Shadow of Authoritarianism.” Presented at the New Politics of Authoritarianism conference, Oxford, March 15, 2017.

Dukalskis, Alexander. 2017. Authoritarian Public Sphere: Legitimation and Autocratic Power in North Korea, Burma, and China. London: Routledge.

Dukalskis, Alexander and Johannes Gerschewski. 2017. "What Autocracies Say (and What Citizens Hear): Proposing Four Mechanisms of Autocratic Legitimation." Contemporary Politics 23(3): 251-68.

Easton, David. 1965. A Systems Analysis of Political Life. New York: John Wiley \& Sons.

Fishkin, James S., Baogang He, Robert C. Luskin, and Alice Siu. 2010. "Deliberative Democracy in an Unlikely Place: Deliberative Polling in China." British Journal of Political Science 40(2): 435-48.

Freeden, Michael. 1994."Political Concepts and Ideological Morphology," Journal of Political Philosophy 2(2): 140-64.
2009. "Languages of Political Support:

Engaging with the Public Realm." Critical Review of International Social and Political Philosophy 12(2): 183-202.

Friedrich, Carl Joachim. 1957. Totalitäre Diktatur. Stuttgart: Kohlhammer.

Fuchs, Dieter and Hans-Dieter Klingemann. 2009. "David Easton: The Theory of the Political System." In Masters of Political Science, ed. Donatella Campus and Gianfranco Pasquino. Colchester: ECPR Press.

Gandhi, Jennifer. 2008. Political Institutions under Dictatorship. New York: Cambridge University Press.

Gandhi, Jennifer and Ellen Lust-Okar. 2009. "Elections under Authoritarianism." Annual Review of Political Science 12: 403-22.

Gandhi, Jennifer and Adam Przeworski. 2007. "Authoritarian Institutions and the Survival of Autocrats." Comparative Political Studies 40(11): 1279-301.

Geddes, Barbara. 1999. "What Do We Know about Democratization after Twenty Years." Annual Review of Political Science 2: 115-44.

Geddes, Barbara and John Zaller. 1989. "Sources of Popular Support for Authoritarian Regimes." American Journal of Political Science 33(2): 319-47.

Gerring, John. 1999. "What Makes a Concept Good? A Criterial Framework for Understanding Concept Formation in the Social Sciences." Polity 31(3): 357-93.

Gerschewski, Johannes. 2013. "The Three Pillars of Stability: Legitimation, Repression, and Co-optation in Autocratic Regimes." Democratization 20(1): 13-38.

Gert, Bernard. 2013. "Loyalty and Morality." In Loyalty. Ed. S. Levinson, J. Parker, and P. Woodruff. New York: New York University Press.

Gill, Graeme. 2015. Building an Authoritarian Polity: Russia in Post-Soviet Times. Cambridge: Cambridge University Press.

Gilley, Bruce. 2009. The Right to Rule: How States Win and Lose Legitimacy. New York: Columbia University Press.

Goertz, Gary. 2006. Social Science Concepts: A User's Guide. Princeton, NJ: Princeton University Press. 2009. "Point of Departure: Intension and Extension." In Concepts and Method in Social Science: The Tradition of Giovanni Sartori. ed. D. Collier and J. Gerring. New York: Routledge.

Grauvogel, Julia and Christian von Soest. 2014. "Claims to Legitimacy Matter: Why Sanctions Fail to Instigate Democratisation in Authoritarian Regimes." European Journal of Political Research 53(3): 635-53.

Han, Rongbin. 2015. "Defending the Authoritarian Regime Online: China's 'Voluntary Fifty-Cent Army.” China Quarterly (224): 1006-25.

Hardin, Russell. 1999. "Do We Want Trust in Government." In Democracy and Trust, ed. Mark E. Warren. New York: Cambridge University Press. 
Haggard, Stephan and Marcus Noland. 2011. Witness to Transformation. Refugee Insights into North Korea.

Washington, DC: Peterson Institute for International Economics.

Haldenwang, Christian von. 2017. "The Relevance of Legitimation: A New Framework for Analysis." Contemporary Politics 23(3): 269-86.

He, Baogang and Mark E. Warren. 2011. "Authoritarian Deliberation. The Deliberative Turn in Chinese Political Development." Perspectives on Politics 9(2): 269-89.

Hirschman, Albert O. 1970. Exit, Voice, and Loyalty: Responses to Declines in Firms, Organizations, and States. Cambridge: Harvard University Press. 1993. "Exit, Voice, and the Fate of the German Democratic Republic: An Essay in Conceptual History." World Politics 45(3): 173-202.

Holbig, Heike. 2013. "Ideology after the End of Ideology: China and the Quest for Autocratic Legitimation." Democratization 20(1): 61-81.

Holbig, Heike and Bruce Gilley. 2010. "Reclaiming Legitimacy in China." Politics \& Policy 38(3): 395-422.

Kaase, Max. 1999. "Interpersonal Trust, Political Trust and non-Institutionalised Political Participation in Western Europe." West European Politics 22(3): 1-21.

Kailitz, Steffen and Daniel Stockemer. 2015. "Regime Legitimation, Elite Cohesion and the Durability of Autocratic Regime Types." International Political Science Review 38(3): 332-48.

Kern, Holger L. and Jens Hainmueller. 2009. "Opium for the Masses: How Foreign Media Can Stabilize Authoritarian Regimes." Political Analysis 17(4): 377-99.

Klingemann, Hans-Dieter and Dieter Fuchs, eds. 1995. Citizen and the State. Oxford: Oxford University Press.

Kuran, Timur. 1991. "Now Out of Never: The Element of Surprise in the East European Revolution of 1989." World Politics 44(1): 7-48.

. (1997) Private Truths, Public Lies: The Social Consequences of Preference Falsification. Cambridge, MA: Harvard University Press.

Levi, Margaret. 1997. Consent, Dissent, and Patriotism. New York: Cambridge University Press.

Levi, Margaret and Laura Stoker. 2000. "Political Trust and Trustworthiness." Annual Review of Political Science 3(1): 475-507.

Levi, Margaret, Audrey Sacks, and Tom Tyler. 2009. "Conceptualizing Legitimacy. Measuring Legitimacy Beliefs." American Behavioral Scientist 53(3): 354-75.

Levitsky, Steven and Lucan Way. 2010. Competitive Authoritarianism: Hybrid Regimes after the Cold War. New York: Cambridge University Press.

Magaloni, Beatriz. 2006. Voting for Autocracy: Hegemonic Party Survival and its Demise in Mexico. New York: Cambridge University Press.
2008. "Credible Power-Sharing and the Longevity of Authoritarian Rule." Comparative Political Studies 41(4/5): 715-41.

Malesky, Edmund and Paul Schuler. 2010. "Nodding or Needling: Analyzing Delegates Responsiveness in an Authoritarian Parliament." American Political Science Review 104(3): 482-502.

Marquez, Xavier. 2015. "The Irrelevance of Legitimacy." Political Studies 64(1): 19-34.

Norris, Pippa, ed. 1999. Critical Citizens: Global Support for Democratic Government. Oxford: Oxford University Press.

O’Kane, Rosemary H. T. 1993. "Against Legitimacy." Political Studies 41(3): 471-87.

Pakulski, Jan. 1986. "Legitimacy and Mass Compliance: Reflections on Max Weber and Soviet-Type Societies." British Journal of Political Science 16(1): 35-56.

Pepinsky, Thomas. 2014. "The Institutional Turn in Comparative Authoritarianism." British Journal of Political Science 44(3): 631-53.

Przeworski, Adam. 1991. Democracy and the Market: Political and Economic Reforms in Eastern Europe and Latin America. New York: Cambridge University Press.

Rigby, Thomas Henry and Ferenc Fehér. 1982. Political Legitimation in Communist States. New York: St. Martin's Press.

Sartori, Giovanni. 1970. "Concept Misformation in Comparative Politics." American Political Science Review 64(4): 1033-53.

Sartori, G. 1984. Social Science Concepts. A Systematic Analysis. London: Sage.

Scharpf, Fritz W. 1999. Governing in Europe: Effective and Democratic? Oxford: Oxford University Press.

Schedler, Andreas, ed. 2006. Electoral Authoritarianism: The Dynamics of Unfree Conmpetition. Boulder, CO: Lynne Rienner.

. 2011. "Concept Formation." In International Encyclopedia of Political Science, ed. Bertrand Badie, Dirk BergSchlosser, and Leonardo Morlino. Thousand Oaks: Sage.

. 2013. The Politics of Uncertainty: Sustaining and Subverting Electoral Authoritarianism. Oxford: Oxford University Press.

Shklar, Judith N. 1993. "Obligation, Loyalty, Exile." Political Theory 21(2):,181-97.

Smith, Benjamin. 2005. "Life of the Party: The Origins of Regime Breakdown and Persistence under Single-Party Rule." World Politics 57(3): 421-51.

Svolik, Milan W. 2009. "Power Sharing and Leadership Dynamics in Authoritarian Regimes." American Journal of Political Science 53(2): 477-94. . (2012) The Politics of Authoritarian Rule. New York, NY: Cambridge University Press.

Stromseth, Jonathan, Edmund M. Malesky, and Dimitar Gueorguiev. 2017. China's Governance Puzzle: Enabling Transparency and Participation in a Single-Party State. New York: Cambridge University Press. 
Thyen, Kressen and Johannes Gerschewski. 2017. "Legitimacy and Protest under Authoritarianism: Explaining Student Mobilization in Egypt and Morocco during the Arab Uprising." Democratization. Online First. Available at http://dx.doi.org/10.1080/ 13510347.2017.1314462.

Truex, Rory. 2017. "Consultative Authoritarianism and Its Limits." Comparative Political Studies 50(3): 329-61.

Weatherford, M. Stephen. 1992. "Measuring Political Legitimacy." American Political Science Review 86(1): 149-66.

Weber, Max. 1978 [1922]. Economy and Society: An Outline of Interpretive Sociology. Ed. Guenther Roth and Claus Wittich. 2 vols. Berkeley: University of California Press.
2005 [1922]. Wirtschaft und Gesellschaft: Die Wirtschaft und die gesellschaftlichen Ordnungen und Mächte. Nachlass, ed. Editha Hanke. Vol. 22-4 Max Weber Gesamtausgabe. Tübingen: Mohr.

Wedeen, Lisa. 1999. Ambiguities of Domination: Politics, Rhetoric, and Symbols in Contemporary Syria. Chicago: University of Chicago Press.

Weßels, Bernhard. 2016. "Democratic Legitimacy. Concepts, Measures, Outcome."In How Europeans View and Evaluate Democracy, ed. Monica Ferrín and Hanspeter Kriesi. Oxford: Oxford University Press.

Würtenberger, Thomas. 1982. "Legitimität, Legalität." In Geschichtliche Grundbegriffe: Historisches Lexikon zur politisch-sozialen Sprache in Deutschland, ed. Otto Brunner, Werner Conze, and Reinhart Koselleck. Vol. 3. Stuttgart: Klett-Cotta. 